\title{
KEBERADAAN KOMISI PEMBERANTASAN KORUPSI DALAM SISTEM KETATANEGARAAN DAN IMPLIKASINYA TERHADAP KEWENANGAN KEJAKSAAN DAN KEPOLISIAN REPUBLIK INDONESIA
}

\author{
Oleh: \\ Roy Saphely \\ Bagian Hukum Dinas PUPR Kab. Bandung \\ Roy.saphely@gmail.com
}

\begin{abstract}
ABSTRAK
Keberadaan Komisi Pemberantasan Korupsi (KPK) dalam penegakan hukum terhadap tindak pidana korupsi di Indonesia adalah konstitusional. Keberadaan KPK dipertegas dengan sejumlah putusan dari Mahkamah Kontitusi. Salah satu beban tugas yang diemban oleh KPK terkait kewenangan penyidikan yang tidak dapat dimonopoli oleh kejaksaan atau kepolisian saja. Sistem ketatanegaraan Indonesia membagi kekuasaan menjadi eksekutif, legislatif dan yudikatif. Penempataan Kejaksaan dan Kepolisian sebagai lembaga penegak hukum pada perkara korupsi selain KPK, memunculkan permaslahan berupa kemandirian Kejaksaan dan Kepolisian, terutama terkait dengan penyidikan perkara korupsi. Hal ini dapat dilihat dari Jaksa Agung dan Kapolri yang diangkat dan diberhentikan oleh Presiden, sehingga dapat memungkinkan adanya intervensi politik. Kewenangan penuntutan yang ada pada KPK sudah tepat karena lembaga ini bergerak secara independen tanpa intervensi kekuasaan manapun.
\end{abstract}

Kata kunci: kewenangan, korupsi, sistem ketatanegaraan.

\begin{abstract}
The existing Anti-Corruption Commission is constitutional, it is reinforced by a number of decisions of the Constitutional Court. Investigative authority can not be monopolized by the Attorney or the police alone. Indonesia constitutional system regulate the distribution of power to executive, legislative and judiciary. to see that the prosecution and the police are still within the scope of the executive or government so that its independence is questionable. It can be seen from the Attorney General and the Chief of Police who is appointed and dismissed by the President, so as to allow for political intervention. Therefore existing prosecutorial powers on the Commission was appropriate because these institutions operate independently without the intervention of any authority.
\end{abstract}

Key words: authority, corruption, constitutional system.

\section{A. Pendahuluan}

"Negara Republik Indonesia adalah Negara Hukum", sebagaimana ditegaskan dalam Pasal 1 ayat (3) Undang-undang Dasar Negara Republik Indonesia Tahun 1945. Norma ini bermakna bahwa di dalam Negara Republik Indonesia, hukum merupakan urat nadi dari seluruh aspek kehidupan dan hukum mempunyai posisi yang strategis dan dominan dalam kehidupan berbangsa, bernegara, dan bermasyarakat.

Hukum sebagai suatu sistem diupayakan dapat berperan dengan baik dan benar di tengah masyarakat, diperlukan institusi-institusi yang dilengkapi dengan kewenangan-kewenangan dalam bidang penegakan hukum. Sistem hukum menurut Lawrence Meir Friedman tersusun dari sub-sub sistem hukum berupa substansi hukum, struktur hukum dan budaya hukum. Ketiga unsur sistem hukum (Three Elements of Legal System) ini sangat menentukan apakah suatu sistem hukum dapat berjalan dengan baik atau tidak. Substansi hukum biasanya menyangkut aspek-aspek pengaturan hukum atau peraturan perundang-undangan. Struktur hukum penekanannya 
lebih kepada aparatur serta sarana dan prasarana hukum itu sendiri. Sementara budaya hukum menyangkut perilaku masyarakatnya. ${ }^{1}$

Guna mewujudkan prinsip-prinsip negara hukum, selain diperlukan normanorma hukum atau peraturan perundang-undangan, juga diperlukan aparatur pengemban dan penegak hukum yang profesional, berintegritas dan disiplin serta didukung oleh sarana dan prasarana hukum serta perilaku hukum masyarakat. Oleh karena itu, idealnya setiap negara hukum termasuk Negara Indonesia harus memiliki aparat penegak hukum, sebagaimana di kemukakan oleh Soerjono Soekanto bahwa "hukum dan penegak hukum merupakan sebagian faktor penegakan hukum yang tidak bisa diabaikan, jika diabaikan akan menyebabkan tidak tercapainya penegakan hukum yang diharapkan". ${ }^{2}$

Penegakan hukum di Indonesia pada saat ini marak terbaca, terdengar, maupun terlihat diberbagai media massa adalah tentang penegakan hukum terhadap tindak pidana korupsi. Sering kita dapati berbagai berita tentang penyidikan, penuntutan, persidangan dari tingkat Pengadilan Negeri, banding, kasasi, bahkan Peninjauan Kembali (PK), hingga pada masalah eksekusi terhadap terpidana kasus korupsi. Berbagai kasus korupsi sering muncul dari kasus-kasus yang bergengsi sampai kasus-kasus korupsi yang terjadi di daerah-daerah, namun yang sering terlewatkan dari ramainya penegakan hukum terhadap kasus-kasus korupsi tersebut adalah mengenai penyidikan.

Indonesia dalam penegakan hukum terhadap tindak pidana korupsi berada di bawah wewenag tiga instansi, yaitu Kejaksaan, Kepolisian, dan Komisi Pemberantasan Korupsi (KPK), ketiga lembaga ini mememiliki kewenangan untuk melakukan penyidikan terhadap tindak pidana korupsi Pertanyaan yang timbul adalah Bagaimana hubungan ketiga instansi tersebut dalam pelaksanaan kewenangan penyidikan dalam kasus tindak pidana korupsi?

Realita yang terjadi sebuah kasus dimana POLRI ikut serta melakukan penyidikan terhadap tindak pidana korupsi yang telah dilakukan oleh KPK, yaitu pada kasus Simulator Surat Ijin Mengemudi (SIM). Dalam kasus tersebut, KPK telah lebih dulu melakukan penyidikan dan menetapkan tersangkanya. Namun tiba-tiba pihak kepolisian juga ikut menetapkan tiga orang sebagai tersangka lainnya dalam kasus tersebut. Pasal 11 huruf a Undang-undang nomor 30 tahun 2002 tentang Komisi Pemberantasan Korupsi (KPK), telah ditegaskan bahwa yang berwenang melakukan penyelidikan, penyidikan dan penuntutan terhadap tindak pidana korupsi yang melibatkan aparat penegak hukum, penyelenggara negara dan orang lain yang ada kaitannya dengan tindak pidana korupsi yang dilakukan oleh aparat penegak hukum atau penyelenggara negara adalah KPK. Penyidikan kasus simulator SIM menjadi bagian dari wewenang kepolisian berdasarkan atau berpedoman kepada MoU yang telah disepakati bersama oleh POLRI, KPK dan Kejaksaan, kesepakatan itu tertuang dalam Kesepakatan Bersama Antara Kejaksaan Republik Indonesia, Kepolisian Negara Republik Indonesia, Komisi Pemberantasan Korupsi Republik Indonesia. Nomor: KEP-049/A/J.A/03/2012, nomor: B/23/III/2012, dan nomor: SP3-39/01/03/2012 Tentang Optimalisasi Pemberantasan Tindak Pidana Korupsi.

Berikut kesepakatan dimaksud yang ditandatangani pada tanggal 29 Maret 2012 di Kejagung, yaitu bagian kedua tentang Penanganan Perkara Tindak Pidana Korupsi, pasal 8:

1. Dalam hal para pihak melakukan penyelidikan pada sasaran yang sama, untuk menghindari duplikasi penyelidikan maka penentuan instansi yang mempunyai kewajiban untuk menindaklanjuti penyelidikan adalah instansi yang lebih

\footnotetext{
${ }^{1}$ Friedmen, Lawrence Meir, The Legal System; A Social Science Perspective, New York, Russel Sage Foundation, 1975, hlm. 11.

${ }^{2}$ Soerjono Soekanto, Faktor-faktor yang Mempengaruhi Penegakan Hukum, Rajawali, Jakarta, 1983, hlm. 5 
dahulu mengeluarkan surat perintah penyelidikan atau atas kesepakatan para pihak.

2. Penyelidikan yang dilakukan pihak kejaksaan dan pihak POLRI diberitahukan kepada pihak KPK, dan perkembangannya diberitahukan kepada pihak KPK paling lama 3 (tiga) bulan sekali

3. Pihak KPK menerima rekapitulasi penyampain bulanan atas kegiatan penyelidikan yang dilaksanakan oleh pihak Kejaksaan dan pihak Polri.

4. Penyelidikan dan penyidikan tindak pidan korupsi oleh salah satu pihak dapat dialihkan ke pihak lain sesuai ketentuan peraturan perundang-undangan, dengan terlebih dahulu dilakukan gelar perkara yang dihadiri oleh para pihak, yang pelaksanaannya dituangkan dalam Berita Acara.

Pihak kepolisian mengatakan telah melakukan penyelidikan sejak tanggal 21 Mei 2012, dan KPK mengklaim telah melakukan penyelidikan sejak tanggal 20 Januari 2012 dan meningkatkan ke tahap penyidikan pada tanggal 27 Juli 2012.

Beranjak dari kasus tersebut di atas peraturan perundang-undangan yang mengatur mengenai Komisi Pemberantasan Korupsi (KPK) dalam penyidikan adalah mengambil alih wewenang dari instansi lain, adapun pengambilalihan tersebut didasarkan pada alasanalasan tertentu yang diatur pada Pasal 9 UU No. 30 Tahun 2002 Tentang Komisi Pemberantasan Korupsi, antara lain :

a. Laporan masyarakat mengenai tindak pidana korupsi tidak ditindak lanjuti;

b. Proses penanganan tindak pidana korupsi secara berlarut-larut atau tertunda-tunda tanpa alasan yang dapat dipertanggungjawabkan;

c. Penanganan tindak pidana korupsi ditujukan untuk melindungi pelaku tindak pidana korupsi yang sesungguhnya;

d. Penanganan tindak pidana korupsi mengandung unsur korupsi;

e. Hambatan penanganan tindak pidana korupsi karena campur tangan dari eksekutif, yudikatif, dan legislativ;

f. Keadaan lain yang menurut petimbangan Kepolisian atau Kejaksaan, penanganan tindak pidana korupsi sulit dilaksanakan secara baik dan dapat dipertanggung jawabkan.

Ketika Undang-undang Nomor 2 Tahun 2002 Tentang Kepolisian Negara Republik Indonesia dan Undang-undang Nomor 30 Tahun 2002 Tentang Komisi Pemberantasan Tindak Pidana Korupsi diberlakukan, fungsi penyidikan dan penuntutan terhadap tindak pidana korupsi yang selama ini merupakan sebagian tugas dan wewenang Kejaksaan RI mengalami perubahan. Ironinya pembuat undang-undang bertindak ambigu karena produk legislasi yang dihasilkan tidak mempunyai landasan filosofi yang jelas untuk mengatasi masalah yang sedang dihadapi, baik masalah hukum masa kini (ius constitutum), masalah implementasi hukum (ius operatum) maupun masalah hukum yang dicita-citakan di masa depan (ius constituendum), ${ }^{3}$ di satu sisi dalam Kitab Undang-Undang Hukum Pidana (KUHAP) memisahkan fungsi penyidikan, penuntutan dan pemeriksaan dalam proses persidangan kecuali terhadap tindak pidana korupsi yang kesemuanya diarahkan ke dalam Sistem Peradilan Pidana Terpadu (Integrated Criminal Justice System), tetapi di sisi lain dengan diberlakukannya Undang-undang Nomor 26 Tahun 1999 Tentang Peradilan Hak Asasi Manusia, Kejaksaan diberi lagi kewenangan menyidik pelanggaran HAM berat yang diatur di dalam Pasal 11 dan 12 undang- undang tersebut serta menyatukan lagi kewenangan

\footnotetext{
${ }^{3}$ Romli Atmasasmita, Reformasi Hukum, Hak Asasi Manusia dan Penegakan Hukum, CV. Mandar Maju, Bandung,
} 2001, hlm. 92. 
penyidikan dan penuntutan kepada Komisi Pemberantasan Tindak Pidana Korupsi, sehingga membuat produk legislasi tersebut relatif tidak dapat bertahan lama.

Khusus berkaitan dengan pemberantasan tindak pidana korupsi sebelum keluarnya Undang-undang Nomor 30 Tahun 2002 Tentang Komisi Pemberantasan Tindak Pidana Korupsi, bermacam upaya telah dilakukan pemerintah yaitu antara beberapa lembaga berikut ini : membentuk Tim Pemberantasan Korupsi (TPK) tahun 1967 s/d 1982 dibawah kendali Jaksa Agung diketuai Jaksa Agung Sugih Arto, Komisi Empat (K4) Januari - Mei 1970 diketuai Wilopo, Komite Anti-Korupsi (KAK) JuniAgustus 1970 beranggotakan Angkatan 66 seperti Akbar Tanjung, dkk, Operasi Penertiban (Opstib, berdasarkan Inpres No.9 Tahun 1977) beranggotakan Menpan, Pangkopkamtib dan Jaksa Agung dibantu pejabat di daerah dan Kapolri, Tim Pemberantasan Korupsi (tahun 1982) diketuai MA Mudjono, selanjutnya berdasarkan Peraturan Pemerintah Nomor 19 Tahun 2000 dibentuk Tim Gabungan Pemberantasan Tindak Pidana Korupsi diketuai Adi Handoyo, SH dan Komisi Pemeriksa Kekayaan Penyelenggara Negara (KPKPN) yang diketuai Yusuf Syakir. Pembentukan Komisi Pemberantasan Tindak Pidana Korupsi (KPK) berdasarkan Undang-undang Nomor 30 Tahun 2002 Tentang Komisi Pemberantasan Tindak Pidana Korupsi yang disahkan pada tanggal 27 Desember 2002 yang merupakan tindak lanjut dari pelaksanaan Undang-undang Nomor 31 Tahun 1999 Pasal 43 yang telah dirubah dengan Undangundang Nomor 20 Tahun 2001 Tentang Pemberantasan Tindak Pidana Korupsi.

Ketentuan Pasal 43 UU No. 31 Tahun 1999, disebutkan tentang perlu adanya Komisi Pemberantasan Tindak Pidana Korupsi (sekarang bernama Komisi Pemberantasan Korupsi) yang harus dibentuk paling lama 2 (dua) tahun setelah disahkannya UU No. 31 Tahun 1999. Kendala dalam memberantas korupsi di Indonesia ialah terlalu banyaknya orang yang akan terkena jika undang-undang pemberantasan korupsi dijalankan sungguhsungguh, akan terjadi saling tuding siapa yang menyidik siapa. Begitu pula hakim yang mengadili, diapun semestinya diadili. Penasehat hukumpun ada yang terlibat kolusi dengan penegak hukum, sehingga mereka sendiri perlu penasihat hukum. Terjadi lingkaran setan yang tidak berujung pangkal. ${ }^{4}$

Sejak Komisi Pemberantasan Tindak Pidana Korupsi ini belum terbentuk sampai terbentuknya, suara sumbang muncul ke permukaan karena adanya kekhawatiran akan adanya ego sektoral, mengingat kewenangan yang begitu besar sebagai lembaga super power. Disamping itu tidak dibatasi prosedur khusus memeriksa pejabat negara dan rahasia bank dan juga dapat mengambil alih penyidikan tindak pidana korupsi yang dilakukan oleh Kepolisian maupun Kejaksaan. Hal lain yang dikhawatirkan adalah konflik kepentingan antar institusi yang mempunyai kewenangan yang sama dan biaya yang dibutuhkan cukup besar untuk memenuhi sarana dan prasarana, baik manyangkut perangkat lunak (software) maupun perangkat keras (hardware) dari institusi tersebut.

Komisi Pemberantasan Korupsi (KPK) diharapkan dapat menjadi institusi yang ampuh dalam proses penyelidikan, penyidikan, dan penuntutan tindak pidana korupsi, karena sifatnya yang independen. Keberadaan atau pembentukan Komisi Pemberantasan Korupsi (KPK) yang merupakan amanat dari diundangkannya Undang-undang No. 31 Tahun 1999, sudah barang tentu nantinya bukan berarti tidak ada masalah, mengingat bahwa saat ini sudah ada lembaga penyidik untuk tindak pidana korupsi dalam hal ini kepolisian dan kejaksaaan. Antara kepolisian dan kejaksanan sendiri hingga saat ini masih terdapat perbedaan persepsi dalam melakukan fungsi penyidikan atas suatu tindak pidana

\footnotetext{
${ }^{4}$ Andi Hamzah, Perbandingan Pemberantasan Korupsi di Berbagai Negara, Jakarta, PT. Sumber Ilmu Jaya, 2002, hlm. 4. 
korupsi. Masing-masing lembaga penyidik tersebut mempunyai dalil yang berdasarkan pada dasar hukum yang secara implisit maupun eksplisit bisa diterima.

Bertambahnya lembaga yang berwenang untuk melakukan fungsi penyidikan dalam hal ini KPK yang secara jelas dan sudah pasti akan menimbulkan reaksi baik yang pro dan kontra atas dibentuknya KPK dimaksud. Sebagai suatu amanat dari Undang-Undang No. 31 Tahun 1999 maka keberadaan atau pembentukan dari KPK adalah suatu keharusan yang tidak bisa ditawar-tawar lagi, namun di lain pihak bahwa dengan terbentuknya KPK yang mempunyai tugas dan wewenang melakukan penyidikan tindak pidana korupsi rentan dipermasalahkan atau dipertentangkan dengan lembaga yang telah ada sebelumnya dalam hal ini kejaksaan dan kepolisian.

Permasalahan yang menarik berkaitan dengan dibentuknya KPK dengan tujuan untuk membantu penegak hukum dalam menanggulangi tindak pidana korupsi di Indonesia, apakah KPK bisa berjalan secara efektif atau tidak dalam menjalankan salah satu fungsinya yaitu melakukan penyidikan tindak pidana korupsi, karena kewenangan yang diberikan oleh Undang-Undang No. 31 Tahun 1999 tentang Pemberantasan Tindak Pidana Korupsi dan harus diemban oleh KPK ternyata jauh lebih luas apabila dibandingkan dengan lembaga kepolisian manapun kejaksaan. Undang-Undang No. 31 Tahun 1999 Pasal 43 ayat (2) jelas sekali dinyatakan bahwa KPK mempunyai kewenangan yang agak berbeda disamping terdapat persamaan dengan lembaga Kepolisian dan Kejaksaan. Adapun wewenang dari KPK adalah melakukan koordinasi dan supervise, termasuk melakukan penyelidikan, penyidikan dan penuntutan sesuai dengan peraturan perundangundangan yang berlaku.

Perbandingan yang dapat dilakukan mengenai kewenangan lembaga kepolisian dan KPK, maka kedua lembaga ini memiliki persamaan dalam menjalankan fungsinya yaitu melakukan penyelidikan dan penyidikan. Sedangkan dengan Kejaksaan persamaannya yaitu dalam hal penyidikan dan melakukan penuntutan. Terlepas dari hal tersebut di atas baik adanya persamaan maupun perbedaan dengan lembaga yang telah ada sebelumnya dalam hal ini kepolisian dan kejaksaan yang menjadi titik berat penulisan ini atas keberadaan atau dibentuknya KPK dalam rangka pemberantasan tindak pidana korupsi ini, apakah bisa berjalan efektif dan sesuai dengan tujuan dibuatnya UU No. 31 tahun 1999.

Penelitian ini difokuskan pada peraturan perundang-undang yang berkaitan dengan Hukum Tata Negara pada umumnya dan Peraturan Perundang- undangan yang berkaitan dengan kewenangan POLRI, dan Kejaksaan Republik Indonesia serta Komisi Pemberantasan Korupsi dalam sistem ketatanegaraan Indonesia. Oleh karena itu, berdasarkan sifatnya penelitian ini termasuk jenis penelitian deskriptif (deskriptif analitis), karena pada dasarnya menggambarkan fenomena atau gejala yang berkenaan dengan kewenangan POLRI, dan Kejaksaan Republik Indonesia serta Komisi Pemberantasan Korupsi. Pendekatannya adalah penelitian yuridis normatif (legal research), dan didukung metode penelitian yuridis empiris.

Penelitian ini difokuskan pada peraturan perundang-undang yang berkaitan dengan Hukum Tata Negara pada umumnya dan Peraturan Perundang- undangan yang berkaitan dengan kewenangan POLRI, dan Kejaksaan Republik Indonesia serta Komisi Pemberantasan Korupsi dalam sistem ketatanegaraan Indonesia. Oleh karena itu, berdasarkan sifatnya penelitian ini termasuk jenis penelitian deskriptif (deskriptif analitis), karena pada dasarnya menggambarkan fenomena atau gejala yang berkenaan dengan kewenangan POLRI, dan Kejaksaan Republik Indonesia serta Komisi Pemberantasan Korupsi. Pendekatannya adalah penelitian yuridis normatif (legal research), dan didukung metode penelitian yuridis empiris. 


\section{B. Pembahasan}

Konsep klasik di banyak negara mengenai pemisahan kekuasaan tersebut dianggap tidak lagi relevan karena tiga fungsi kekuasaan yaitu eksekutif, legislatif dan yudikatif tidak mampu menanggung beban negara dalam menyelenggarakan pemerintahan. Untuk menjawab tuntutan tersebut, negara membentuk berbagai jenis lembaga negara baru yang diharapkan dapat lebih responsif dalam mengatasi persoalan aktual negara. Maka, berdirilah berbagai lembaga negara yang membantu tugas lembaga-lembaga negara tersebut yang menurut Jimly Asshidiqie disebut sebagai "Lembaga Negara Bantu" dalam bentuk dewan, komisi, komite, badan, ataupun otorita, dengan masing-masing tugas dan wewenangnya. Beberapa ahli tetap mengelompokkan lembaga negara bantu dalam lingkup eksekutif, namun ada pula sarjana yang menempatkannya tersendiri sebagai cabang keempat. Kehadiran lembaga negara bantu di Indonesia menjamur pasca perubahan UUD 1945.

Berbagai lembaga negara bantu tersebut tidak dibentuk dengan dasar hukum yang seragam. Beberapa di antaranya berdiri atas amanat konstitusi, namun ada pula yang memperoleh legitimasi berdasarkan undang-undang ataupun keputusan Presiden. Salah satu lembaga negara bantu yang dibentuk dengan Undang-Undang adalah Komisi Pemberantasan Korupsi (KPK). Walaupun bersifat independen dan bebas dari kekuasaan manapun, KPK tetap bergantung kepada kekuasaan eksekutif dalam kaitan dengan masalah keorganisasian, dan memiliki hubungan khusus dengan kekuasaan yudikatif dalam hal penyelidikan dan persidangan perkara tindak pidana korupsi.

Munculnya lembaga negara bantu di Indonesia dimulai dari runtuhnya era Presiden Soeharto. Kemunculan lembaga baru seperti ini pun bukan merupakan satunya-satunya di dunia. Di negara yang sedang menjalani proses transisi menuju demokrasi juga lahir lembaga tambahan negara yang baru. Berdirinya lembaga negara bantu merupakan perkembangan baru dalam sistem pemerintahan. Teori klasik trias politica sudah tidak dapat lagi digunakan untuk menganalisis relasi kekuasaan antar lembaga negara. ${ }^{5}$

Penentuaan institusi mana saja yang disebut sebagai lembaga negara bantu dalam struktur ketatanegaraan RI terlebih dahulu harus dilakukan pemilahan terhadap lembagalembaga negara berdasarkan dasar pembentukannya. Pasca perubahan konstitusi, Indonesia membagi lembaga- lembaga negara ke dalam tiga kelompok. Pertama, lembaga negara yang dibentuk berdasar atas perintah UUD Negara RI Tahun 1945 (constitutionally entrusted power). Kedua, lembaga negara yang dibentuk berdasarkan perintah undangundang (legislatively entrusted power). Dan ketiga, lembaga negara yang dibentuk atas dasar perintah keputusan Presiden.

Lembaga negara pada kelompok pertama adalah lembaga-lembaga negara yang kewenangannya diberikan secara langsung oleh UUD 1945, yaitu Presiden dan Wakil Presiden, MPR, DPR, DPD, BPK, MA, MK, dan KY. Selain delapan lembaga tersebut, masih terdapat beberapa lembaga yang juga disebut dalam UUD Negara RI Tahun 1945 namun kewenangannya tidak disebutkan secara eksplisit oleh konstitusi. Lembagalembaga yang dimaksud adalah Kementerian Negara, Pemerintah Daerah, Komisi Pemilihan Umum, Bank Sentral, Tentara Nasional Indonesia (TNI), Kepolisian Negara Republik Indonesia (Polri), dan Dewan Pertimbangan Presiden. Satu hal yang perlu ditegaskan adalah kedelapan lembaga negara yang sumber kewenangannya berasal langsung dari konstitusi tersebut merupakan pelaksana kedaulatan rakyat dan berada dalam suasana yang setara, seimbang, serta independen satu sama lain.

\footnotetext{
5 Fariz Pradipta, Kedudukan Lembaga Negara Bantu dalam Sistem Hukum Ketatanegaraan Indonesia, http://farizpradiptalaw.blogspot.com/2009/12/kedudukan-lembaga-negara-bantu-di dalam.html, diakses pada tanggal 26 Februari 2013.
} 
Berikutnya, berdasarkan catatan lembaga swadaya masyarakat Konsorsium Reformasi Hukum Nasional (KRHN), paling tidak terdapat sepuluh lembaga negara yang dibentuk atas dasar perintah Undang-Undang. Lembaga-lembaga tersebut adalah Komisi Nasional Hak Asasi Manusia (Komnas HAM), Komisi Pemberantasan Korupsi (KPK), Komisi Penyiaran Indonesia (KPI), Komisi Pengawas Persaingan Usaha (KPPU), Komisi Kebenaran dan Rekonsiliasi (KKR), Komisi Nasional Perlindungan Anak Indonesia (Komnas Perlindungan Anak), Komisi Kepolisian Nasional, Komisi Kejaksaan, Dewan Pers, dan Dewan Pendidikan. Jumlah ini kemungkinan dapat bertambah atau berkurang mengingat lembaga negara dalam kelompok ini tidak bersifat permanen melainkan bergantung pada kebutuhan negara. Misalnya, KPK dibentuk karena dorongan kenyataan bahwa fungsi lembaga-lembaga yang sudah ada sebelumnya, seperti Kepolisian dan Kejaksaan, dianggap tidak maksimal atau tidak efektif dalam melakukan pemberantasan korupsi. Apabila kelak, korupsi dapat diberantas dengan efektif oleh Kepolisian dan Kejaksaan, maka keberadaan KPK dapat ditinjau kembali.

Lembaga negara pada kelompok terakhir atau yang dibentuk berdasarkan perintah dan kewenangannya diberikan oleh Keputusan Presiden antara lain adalah Komisi Ombudsman Nasional (KON), Komisi Hukum Nasional (KHN), Komisi Nasional Antikekerasan terhadap Perempuan (Komnas Perempuan), Dewan Maritim Nasional (DMN), Dewan Ekonomi Nasional (DEN), Dewan Pengembangan Usaha Nasional (DPUN), Dewan Riset Nasional (DRN), Dewan Pembina Industri Strategis (DPIS), Dewan Buku Nasional (DBN), serta lembaga-lembaga non-departemen. Sejalan dengan lembagalembaga negara pada kelompok kedua, lembaga-lembaga negara dalam kelompok yang terakhir ini pun bersifat sementara bergantung pada kebutuhan negara. ${ }^{6}$

Lembaga-lembaga negara dalam kelompok kedua dan ketiga inilah yang disebut sebagai lembaga negara bantu. Pembentukan lembaga-lembaga negara yang bersifat mandiri ini secara umum disebabkan oleh adanya ketidakpercayaan publik terhadap lembaga-lembaga negara yang ada dalam menyelesaikan persoalan ketatanegaraan. Selain itu, pada kenyataannya lembaga-lembaga negara yang telah ada belum berhasil memberikan jalan keluar dan menyelesaikan persoalan yang ada ketika tuntutan perubahan dan perbaikan semakin mengemuka seiring dengan berkembangnya paham demokrasi di Indonesia. $^{7}$

Beberapa orang sebagai pemohon mengajukan judicial review kepada MK dengan mempersoalkan eksistensi KPK dengan menghadapkan pasal 2, pasal 3, dan pasal $20 \mathrm{UU}$ KPK dengan pasal 1 ayat (3) UUD 1945 tentang negara hukum. Mereka berpendapat bahwa ketiga pasal UU KPK tersebut bertentangan dengan konsep negara di dalam UUD 1945 yang telah menetapkan delapan organ negara yang mempunyai kedudukan yang sama atau sederajat yang secara langsung mendapat fungsi konstitusional dari UUD 1945 yaitu MPR, Presiden, DPR, DPD, BPK, MA, MK, dan KY.

Pembentukan lembaga-lembaga negara bantu tersebut juga harus memiliki landasan pijak yang kuat dan paradigma yang jelas. Dengan demikian, keberadaannya dapat membawa manfaat bagi kepentingan publik pada umumnya serta bagi penataan sistem ketatanegaraan pada khususnya. ${ }^{8}$ Ni'matul Huda, mengutip Firmansyah Arifin,dkk. dalam bukunya Lembaga Negara dan Sengketa Kewenangan Antar lembaga Negara, mengatakan bahwa aspek kuantitas lembaga-lembaga tersebut tidak menjadi masalah asalkan keberadaan dan pembentukannya mencerminkan prinsip-prinsip sebagai berikut:

1. Prinsip konstitusionalisme. Konstitusionalisme adalah gagasan yang menghendaki agar kekuasaan para pemimpin dan badan-badan pemerintahan yang ada dapat

\footnotetext{
${ }^{6}$ Ibid.

${ }^{7}$ Ibid.

${ }^{8}$ Ibid.
} 
dibatasi. Pembatasan tersebut dapat diperkuat sehingga menjadi suatu mekanisme yang tetap.

2. Prinsip checks and balances. Ketiadaan mekanisme checks and balances dalam sistem bernegara merupakan salah satu penyebab banyaknya penyimpangan di masa lalu. Supremasi MPR dan dominasi kekuatan eksekutif dalam praktik pemerintahan pada masa prareformasi telah menghambat proses demokrasi secara sehat. Ketiadaan mekanisme saling kontrol antar cabang kekuasaan tersebut mengakibatkan pemerintahan yang totaliter serta munculnya praktik penyalahgunaan kekuasaan atau abuse of power.

3. Prinsip integrasi. Selain harus mempunyai fungsi dan kewenangan yang jelas, konsep kelembagaan negara juga harus membentuk suatu kesatuan yang berproses dalam melaksanakan fungsinya. Pembentukan suatu lembaga negara tidak dapat dilakukan secara parsial, melainkan harus dikaitkan keberadaannya dengan lembaga-lembaga lain yang telah eksis.

4. Prinsip kemanfaatan bagi masyarakat. Pada dasarnya, pembentukan lembaga negara ditujukan untuk memenuhi kesejahteraan warganya serta menjamin hak-hak dasar warga negara yang diatur dalam konstitusi. Oleh karena itu, penyelenggaraan pemerintahan serta pembentukan lembaga-lembaga politik dan hukum harus mengacu kepada prinsip pemerintahan, yaitu harus dijalankan untuk kepentingan umum dan kebaikan masyarakat secara keseluruhan serta tetap memelihara hak-hak individu warga negara. ${ }^{9}$

Pendapat yang menyatakan bahwa keberadaan KPK dalam sistem ketatanegaraan Indonesia adalah ekstrakonstitusional karena lembaga ini tidak disebutkan dan diatur dalam UUD 1945 sebagai konstitusi Indonesia, adalah keliru. Keberadaan atau terbentuknnya KPK walaupun tidak disebutkan dalam UUD 1945, namun keberadaan KPK secara tegas diatur dalam Undang-Undang No. 30 Tahun 2002 tentang KPK.

Pendapat tersebut seharusnya memperhatikan bahwa Indonesia sebagai negara hukum mengakui keberadaan KPK sebagai salah satu lembaga negara yang sifatnya konstitusional. Penjelasan di atas memberi arti bahwa KPK sebagai salah satu lembaga negara dalam sistem ketatanegaraan adalah konstitusional dan dibentuk karena adanya realita yang terjadi bahwa saat ini masalah korupsi di Indonesia merupakan masalah yang sangat penting untuk diberantas dan diprioritaskan penanganannya sehingga diperlukan suatu lembaga negara bantu seperti KPK untuk menangani dan memberantas masalah korupsi.

KPK dalam melaksanakan tugasnya mempunyai kejelasan yaitu jaksanya adalah jaksa fungsional dari Kejaksaan Agung, hakimnya diangkat oleh Mahkamah Agung, bahkan kasasinya juga ke Mahkamah Agung. KPK dan lembaga lain dalam proses peradilan itu terajut dalam hubungan umum dan khusus. ${ }^{10}$ Ada tiga prinsip yang dapat dipergunakan untuk menjelaskan soal eksistensi KPK. Yaitu :

Pertama, dalil yang berbunyi salus populi supreme lex, yang berarti keselamatan rakyat (bangsa dan negara) adalah hukum yang tertinggi. Jika keselamatan rakyat, bangsa, dan negara sudah terancam karena keadaan yang luar biasa maka tindakan apapun yang sifatnya darurat atau khusus dapat dilakukan untuk menyelamatkannya. Dalam hal ini, kehadiran KPK dipandang sebagai keadaan darurat untuk menyelesaikan korupsi yang sudah luar biasa. ${ }^{11}$

\footnotetext{
${ }^{9}$ Ibid.

${ }^{10}$ Moh. Mahfud MD, Demokrasi dan Konstitusi Di Indonesia, hlm. 197.

${ }^{11}$ Ibid.
}

82 KEBERADAAN KOMISI PEMBERANTASAN KORUPSI DALAM SISTEM KETATANEGARAAN DAN IMPLIKASINYA TERHADAP KEWENANGAN KEJAKSAAN DAN KEPOLISIAN REPUBLIK INDONESIA 
Kedua, di dalam hukum dikenal adanya hukum yang bersifat umum (lex generalis) dan yang bersifat khusus (lex spescialis). ${ }^{12}$ Dalam hukum dikenal asas lex specialis derogate legi generali, yang artinya undang-undang istimewa/khusus didahulukan berlakunya daripada undang-undang yang umum. ${ }^{13}$ Keumuman dan kekhususan itu dapat ditentukan oleh pembuat UU sesuai dengan kebutuhan, kecuali UUD jelas-jelas menentukan sendiri mana yang umum dan mana yang khusus. Dalam konteks ini, KPK merupakan hukum khusus yang kewenangannya diberikan oleh UU selain kewenangankewenangan umum yang diberikan kepada Kejaksaan dan Kepolisian.

Ketiga, pembuat UU (badan legislatif) dapat mengatur lagi lanjutan sistem ketatanegaraan yang tidak atau belum dimuat di dalam UUD sejauh tidak melanggar asasasas dan restriksi yang jelas-jelas dimuat di dalam UUD itu sendiri. Dalam kaitan ini, dipandang bahwa kehadiran KPK merupakan perwujudan dari hak legislasi DPR dan pemerintah setelah melihat kenyataan yang menuntut perlunya itu.

Sulit menerima argumen bahwa keberadaan KPK yang di luar kekuasaan kehakiman dianggap mengacaukan sistem ketatanegaraan, mengingat selama ini Kejaksaan dan Kepolisian pun berada di luar kekuasaan kehakiman. Oleh karena UU telah mengatur hal yang tak dilarang atau disuruh tersebut maka keberadaan KPK sama sekali tak menimbulkan persoalan dalam sistem ketatanegaraan. Tentang persoalan menimbulkan abuse of power, justru hal itu tidak relevan jika dikaitkan dengan keberadaan KPK, sebab abuse of power itu bisa terjadi di mana saja. KPK justru dihadirkan untuk melawan abuse of power yang sudah terlanjur kronis.

Mengenai fungsi Kejaksaan dan Kepolisian di bidang peradilan, adalah UU yang memberikan fungsi kepada lembaga-lembaga itu yang bisa dipangkas atau ditambah oleh pembuat UU itu sendiri. Jadi, ketentuan ini tak dapat dipersoalkan melalui judicial review, sebab pembuat UU itu sudah mengaturnya menjadi seperti itu melalui pengkhususan. Kalau hendak mempersoalkannya, hal itu seharusnya dilakukan melalui legislative review, bukan melalui judicial review.

KPK sebagai lembaga pemberantas korupsi yang diberikan kewenangan yang kuat bukan berada di luar sistem ketatanegaraan, tetapi justru ditempatkan secara yuridis di dalam sistem ketatanegaraan yang rangka dasarnya sudah ada di dalam UUD 1945. KPK juga tidak mengambil alih kewenangan lembaga lain, melainkan diberi atau mendapat kewenangan dari pembuat UU sebagai bagian dari upaya melaksanakan perintah UUD 1945 di bidang penegakan hukum, peradilan, dan kekuasaan kehakiman.

KPK dibentuk sebagai lembaga negara bantu karena adanya isu insidentil menyangkut korupsi di Indonesia pasca era Orde Baru. KPK merupakan aplikasi bentuk politik hukum yang diberikan kewenangan oleh UUD 1945 kepada badan legislatif sebagai pembuat UU.

Peraturan perundang-undangan yang mengatur mengenai Komisi Pemberantasan Korupsi (KPK) dalam penyidikan adalah mengambil alih wewenang dari instansi lain, adapun pengambilalihan tersebut didasarkan pada alasan-alasan tertentu yang diatur pada Pasal 9 UU No. 30 Tahun 2002 Tentang Komisi Pemberantasan Korupsi, antara lain :

a. Laporan masyarakat mengenai tindak pidana korupsi tidak ditindak lanjuti;

b. Proses penanganan tindak pidana korupsi secara berlarut-larut atau tertundatunda tanpa alasan yang dapat dipertanggungjawabkan;

c. Penanganan tindak pidana korupsi ditujukan untuk melindungi pelaku tindak pidana korupsi yang sesungguhnya;

d. Penanganan tindak pidana korupsi mengandung unsur korupsi;

\footnotetext{
12 Ibid.

${ }^{13}$ Adiwinata, Istilah Hukum Latin-Indonesia, PT Intermesa, Jakarta, Cetakan Pertama, 1977, hlm. 63.
} 
e. Hambatan penangan tindak pidana korupsi karena campur tangan dari eksekutif, yudikatif, dan legislatif;

f. Keadaan lain yang menurut petimbangan Kepolisian atau Kejaksaan, penanganan tindak pidana korupsi sulit dilaksanakan secara baik dan dapat dipertanggung jawabkan.

Pasal tersebut menunjukkan tidak ada sengketa/masalah terhadap kewenangan KPK dalam hal penyidikan korupsi, karena tidak mungkin terjadi tumpang tindih kewenangan dengan instansi lain. Namun, yang menjadi masalah adalah kewenangan penyidikan dari kedua instansi lainnya, yaitu Kejaksaan dan Kepolisian, karena tidak ada peraturan perundang-undangan yang membagi kewenangan kedua instansi tersebut dalam melakukan penyidikan terhadap tindak pidana korupsi, sehingga menimbulkan tumpang tindih kewenangan antara ketiga instansi ini. Lebih jelasnya dalam KUHAP pada Pasal 1 ayat (1)

"Penyidik adalah pejabat polisi negara Republik Indonesia atau pejabat pegawai negeri sipil tertentu yang diberi wewenang khusus oleh undang-undang untuk melakukan penyidikan".

Jelas terlihat dengan disebutkan bahwa polisi memiliki wewenang melakukan penyidikan, dalam hal ini penyidikan terhadap setiap tindak pidana yang terjadi, termasuk tindak pidana korupsi, padahal Jaksa juga memiliki wewenang penyidikan terhadap tindak pidana korupsi tersebut. Kewenangan Jaksa tersebut ditunjukkan dalam Pasal 30 ayat (1) huruf d UU No. 16 Tahun 2004 Tentang Kejaksaan Republik Indonesia, yaitu di bidang pidana, kejaksaan mempunyai tugas dan wewenang "Melakukan penyidikan terhadap tindak pidana tertentu berdasarkan Undang-undang”. Penjelasan pasal tersebut "Kewenangan dalam ketentuan ini adalah kewenangan sebagaimana diatur misalnya dalam UU No. 26 Tahun 2000 tentang Pengadilan Hak Asasi Manusia dan UU No. 31 Tahun 1999 tentang Pemberantasan Tindak Pidana Korupsi sebagaimana telah dirubah dengan UU No. 20 Tahun 2001 jo. UU No. 30 Tahun 2002 tentang Komisi Pemberantasan Korupsi”.

Ketentuan mengenai kewenangan Jaksa di atas sebenarnya sekaligus memperkuat Pasal 284 ayat (2) KUHAP yang mendasari kewenangan Jaksa dalam melakukan penyidikan terhadap tindak pidana korupsi, yaitu dalam dua tahun setelah undang-undang ini (KUHAP) diundangkan, maka terhadap semua perkara diberlakukan ketentuan ini, dengan pengecualian untuk sementara mengenai ketentuan khusus acara pidana sebagaimana tersebut dalam undang-undang tertentu, sampai ada perubahan dan atau dinyatakan tidak berlaku lagi.

Penjelasan Pasal di atas menyebutkan bahwa:

a. Yang dimaksud dengan semua perkara adalah perkara yang telah dilimpahkan ke Pengadilan.

b. Yang dimaksud dengan "ketentuan khusus acara pidana sebagaimana tersebut dalam undang-undang tertentu" ialah ketentuan khusus acara pidana sebagaimana tersebut pada, antara lain:

1. Undang-undang tentang Pengusutan, Penuntutan dan Peradilan Tindak Pidana Ekonomi (UU No. 7 Drt. Tahun 1955).

2. Undang-undang tentang Pemberantasan Tindak Pidana Korupsi (UU No. 3 Tahun 1971).

Masih mengenai ketentuan Pasal 284 ayat (2) KUHAP di atas setelah diundangkannya KUHAP, khususnya mengenai "jangka waktu dua tahun", antara Instansi Kejaksaan dan Kepolisian berbeda dalam mengartikannya. Bagi Kejaksaan jangka waktu dua tahun hanyalah penanganan perkara-perkara tindak pidana umum saja, dimana pelanggaran terhadap Kitab Undang-Undang Hukum Pidana (KUHP) sajalah yang menjadi 
kewenangan Polisi untuk menyidik, sehingga walaupun pasal tersebut dicabut maupun tidak, Jaksa tetap berperan sebagai penyidik tunggal untuk perkara-perakara tindak pidana khusus, yaitu perkara tindak pidana subversi, ekonomi, dan korupsi.

Lembaga Kepolisian sendiri berpendapat bahwa apabila "jangka waktu dua tahun" tersebut sudah lewat, maka polisi memiliki wewenang melakukan penyidikan terhadap semua tindak pidana, termasuk tindak pidana khusus. Bukti tersebut menjelaskan sudah adanya tumpang tindih kewenangan antara dua Instansi ini, namun dalam realitanya seakan tidak ada masalah dengan adanya ketumpang tindihan tersebut. Pada prakteknya hubungan antara kedua Instansi tersebut baik-baik saja, namun sebenarnya ada background perselisihan antara kedua instansi tersebut setelah diundangkannya KUHAP, khususnya mengenai Pasal 284 ayat (2). ${ }^{14}$

Sebenarnya dengan adanya kewenangan yang melekat pada kedua instansi tersebut untuk menyidik tindak pidana korupsi memiliki kelebihan maupun kelemahan, kelebihan kewenangan menyidik pada Kejaksaan sendiri yaitu mengingat bahwa ketentuan Pasal 25 UU No. 31 tahun 1999 Tentang Pemberantasan Tindak Pidana Korupsi "Penyidikan, penuntutan, dan pemeriksaan di sidang Pengadilan dalam perkara tindak pidana korupsi harus didahulukan dari perkara lain guna penyelesaian secepatnya".

Berkaitan dengan pasal tersebut khususnya "guna penyelesaian secepatnya" dari perkara-perkara korupsi sendiri, dengan adanya kewenangan penyidikan yang melekat pada kejaksaan diharapkan dapat mempercepat penanganan perkara korupsi, karena Jaksa sebagai Penuntut umum tentunya mengerti benar tentang perkara yang ditanganinya langsung mulai dari penyidikan, sehingga dia juga paham apa saja yang dibutuhkan dalam penuntutan nantinya berdasarkan penyidikan yang dilakukan, dimana hal ini juga untuk menyikapi Pasal 110 ayat (1) dan Pasal 138 ayat (2) KUHAP, yaitu :

a. Pasal 110 ayat (1) KUHAP "Dalam hal penyidik telah selesai melakukan penyidikan, penyidik wajib segera menyerahkan berkas perkara kepada penuntut umum".

b. Pasal 138 ayat (2) KUHAP "Dalam hal hasil penyidikan ternyata belum lengkap, penuntut umum mengembalikan berkas perkara kepada penyidik disertai petunjuk tentang hal yang harus dilakukan untuk dilengkapi dan dalam waktu 14 hari sejak tanggal penerimaan berkas, penyidik harus sudah menyampaikan kemnbali berkas perkara itu kepada penuntut umum".

Kedua Pasal di atas, tentunya bukan masalah jika kewenangan penyidikan ada pada satu atap Kejaksaan, sehingga berkas perkara tidak perlu mondar-mandir dari penyidik dan penuntut umum, karena kekhawatiran mengenai kurang lengkapnya hasil penyidikan dapat teratasi. Namun terdapat kelemahan yang sangat membahayakan jika kewenangan tersebut terdapat pada satu atap karena sering terjadi, bisa saja Jaksa yang melakukan penyidikan dan penuntutan adalah Jaksa yang sama, sehingga fungsi pengawasan antara penuntut umum terhadap penyidik secara prosedur hukum acara tidak berjalan. Hal ini dapat memicu terjadinya penyelewengan terhadap kewenangan tersebut, sangat rentan terjadi suap dalam suatu penanganan suatu perkara korupsi, seperti yang dapat kita lihat sekarang ini mengenai penghentian penyelidikan kasus BLBI, diduga terjadi suap yang melibatkan petinggi-petinggi Jaksa di Kejaksaan Agung.

Begitu juga dengan Kepolisian, terdapat kelebihan maupun kelemahan pada kewenangan penyidikan perkara korupsi. Sebaliknya, jika penyidikan dilakukan oleh Polisi maka cenderung fungsi pengawasan dari penuntut umum terhadap penyidik lebih terealisasi, karena tidak mungkin penuntut umum begitu saja menerima berkas hasil

${ }^{14}$ Sulistyo Utomo, Tumpang Tindih Kewenangan Penyidikan Tindak Pidana Korupsi, Warta Hukum Edisi: Agustus - September, Pusat Pendidikan dan Latihan ( Pusdiklat ) Laboratorium Fakultas Hukum Universitas Islam Indonesia 2008, hlm. 5 
penyidikan dari penyidik, pasti penuntut umum dalam pra-penuntutan mempertimbangkan secara seksama kelengkapan dari hasil penyidikan, sesuai dengan ketentuan kedua Pasal 110 ayat (1) dan 138 ayat (2) KUHAP di atas, karena sejak dimulainya penyidikan, penyidik sudah harus memberitahukan kepada penuntut umum, dan sejak itu pula penanganan perkara sudah dinyatakan pro-justicia, sehingga penuntut umum harus dengan teliti dalam mengawasi kinerja penyidikan oleh penyidik, sebab setelah berkas diterima oleh penuntut umum dan dinyatakan lengkap dan semuanya terpenuhi, tanggung jawab seluruhnya mengenai perkara tersebut sudah beralih dari penyidik ke penuntut umum sampai tahap persidangan.

Namun terdapat juga kelemahan jika penyidikan perkara korupsi disidik oleh pihak Kepolisian. Mengingat bukan hanya tindak pidana khusus yang dapat disidik oleh Kepolisian, tapi juga semua bentuk tindak pidana umum (tindak pidana yang diatur KUHP) disidik oleh Kepolisian, sehingga tentunya perkara yang disidik menumpuk di Kepolisian. Perkara korupsi merupakan extra ordinary crime (kejahatan luar biasa), sehingga dalam penanganannya harus dilakukan secepatnya, sesuai yang diatur dalam Pasal 25 UU No. 31 tahun 1999 Tentang Pemberantasan Tindak Pidana Korupsi. Dikhawatirkan jika Kepolisian menyidik perkara korupsi maka akan memakan waktu yang sangat lama, karena Kepolisian sendiri juga harus menangani penyidikan perkara-perkara pidana umum yang sangat banyak masuk ke instansi tersebut. Selain itu proses pelimpahan berkas penyidikan ke penuntut umum juga akan memakan waktu yang lama pula untuk memperoleh P-21 (kode yang menunjukkan dinyatakan lengkap dan dapat diterimanya hasil penyidikan oleh penuntut umum), karena dalam prakteknya sekarang ini penuntut umum sering mengembalikan berkas penyidikan kepada penyidik Polisi karena dianggap kurang lengkap, sehingga berkas penyidikan akan mondar-mandir diantara dua instansi tersebut, hal ini sangat menghambat sekali penanganan perkara korupsi "secepatnya".

Memang sangat membingungkan untuk menentukan kewenangan penyidikan perkara korupsi di salah satu saja instansi, karena masing-masing instansi yang berwenang menyidik pastilah memiliki kelebihan dan kekurangannya, namun mengingat bahwa negara ini juga sangat memperhatikan kepastian peraturan perundang-undangan, tentunya kebiasan mengenai kewenangan penyidikan perkara korupsi ini perlu diatasi, karena bisa kapan saja terjadi tumpang tindih antara Kejaksaan dan Kepolisian untuk menangani penyidikan suatu perkara korupsi, atau malah sebaliknya, keduanya saling menyodorkan penanganan perkara tersebut, jika terjadi demikian bukan menyelesaikan masalah, tapi justru akan menghambat penanganan.

Korupsi bukanlah perkara yang sepele, korupsi dapat menjegal, mempengaruhi, serta merugikan sendi-sendi perekonomian negara, tapi masih ada kebiasan pengaturan seperti yang kita temui seperti di atas. Tentunya perlu ada kepastian pada kewenangan penyidikannya, seperti kepastian kewenangan penyidikan yang melekat pada Komisi Pemberantasan Korupsi (KPK), dimana ada kepastian kualifikasi kewenangan untuk menyidik maupun tahapan penanganan perkara korupsi lainnya. Begitu juga mengenai kewenangan penyidikan yang ada pada Kejaksaan dan Kepolisian, sebaiknya jangan sampai ada ketumpang tindihan kewenangan seperti sekarang ini, mengingat kembali bahwa negara ini merupakan negara yang tidak mengabaikan suatu kepastian hukum.

Upaya yang dilakukan POLRI, Jaksa, dan KPK untuk menghindari benturan kewenangan telah dilakukan, yaitu dengan disepakatinya MoU antara ketiga instansi tersebut pada tanggal 29 Maret 2012 yang terdiri dari tiga surat yaitu Nomor B/23/III/2012 untuk Kepolisian, Nomor SPJ-39/01/- 03/2012 untuk KPK, dan Nomor KEP-049/A/JA/ 03/2012 untuk Kejaksaan Tentang Optimalisasi Pemberantasan Tindak Pidana Korupsi, akan tetapi upaya ini menemui jalan buntu ketika terjadi benturan kewenangan antara KPK 
dan POLRI dalam kasus simulator SIM. MoU tersebut tidak sejalan dengan argumen masing-masing pihak dan tidak sesuai dengan fakta-fakta terkait.

\section{Penutup \\ Simpulan}

Komisi Pemberantasan Korupsi (KPK) adalah lembaga negara yang sifatnya konstitusional walaupun tidak disebutkan secara jelas dalam konstitusi negara yaitu UUD 1945. KPK dibentuk dengan melihat sifat dari korupsi itu sendiri yaitu merupakan kejahatan luar biasa, sehingga diperlukan suatu lembaga yang independen untuk memberantas korupsi di Indonesia. Latar belakang terbentuknya KPK bukanlah karena desain konstitusional yang diartikan secara kaku, tetapi lebih kepada isu insidentil dalam negara dan kehendak bersama dari bangsa Indonesia untuk memerangi tindak pidana korupsi. Kedudukan KPK sebagai salah satu lembaga negara bantu adalah independen dan bebas dari pengaruh kekuasaan manapun, hal ini dimaksudkan agar dalam memberantas korupsi KPK tidak mendapatkan intervensi dari pihak manapun. Terbentuknya KPK juga merupakan jawaban atas tidak efektifnya kinerja lembaga penegak hukum selama ini dalam memberantas korupsi, yang terkesan berlarut-larut dalam penanganannya bahkan terindikasi ada unsur korupsi dalam penanganan kasusnya.

\section{Daftar Pustaka}

\section{Buku}

Adiwinata, Istilah Hukum Latin-Indonesia, PT Intermesa, Jakarta, Cetakan Pertama, 1977

Andi Hamzah, Perbandingan Pemberantasan Korupsi di Berbagai Negara, Jakarta, PT. Sumber Ilmu Jaya, 2002

Friedmen, Lawrence Meir, The Legal System; A Social Science Perspective, New York, Russel Sage Foundation, 1975

Moh. Mahfud MD, Demokrasi dan Konstitusi Di Indonesia: Studi Tentang Interaksi Poitik dan Anggaran Kehidupan Ketatanegaraan, Jakarta: Rineka Cipta, 2003.

Romli Atmasasmita, Reformasi Hukum, Hak Asasi Manusia dan Penegakan Hukum, CV. Mandar Maju, Bandung, 2001

Sulistyo Utomo, Tumpang Tindih Kewenangan Penyidikan Tindak Pidana Korupsi, Warta Hukum Edisi: Agustus - September, Pusat Pendidikan dan Latihan ( Pusdiklat ) Laboratorium Fakultas Hukum Universitas Islam Indonesia 2008.

Soerjono Soekanto, Faktor-faktor yang mempengaruhi Penegakan Hukum, Rajawali, Jakarta, 1983. 